\title{
Interlocking Intramedullary Nailing without Fluoroscopy in Resource Limited Settings: Outcomes and Outlook
}

\author{
F M Bombah* \\ Department of surgery, Faculty of Medicine and Pharmaceutical Sciences, University of Douala, Cameroon
}

Submission: April 01, 2021; Published: April 16, 2021

*Corresponding author: F M Bombah, Faculty of Medicine and Pharmaceutical Sciences, University of Douala, Cameroon

Abstract

Closed static interlocking nailing with c-arm guidance is the standard procedure for the treatment of closed diaphyseal fractures. In lowincome setting, it is still very difficult to carry out such procedures because of few or absent image intensifiers (c-arm) despite the necessity. Many techniques have been described, mainly on the lower limbs to overcome the lack of fluoroscopy. Open reduction and interlocking nailing using ancillary devices was done for femur diaphyseal fractures. Opened or Closed interlocking nailing for tibia diaphyseal fractures. These techniques were mainly carried out in subsahara Africa and made it possible to highlight the outcomes and perspectives. The common outcomes used are the quality of the nailing, the insertion of the nail, the insertion of locking screws, consolidation and functional outcome. As perspectives some elements of these techniques can be used to decrease the use of $\mathrm{C}$-arm and the exposure to radiation in the operating room. There is a need to improve equipment in sub-Saharan African hospitals to make trauma surgery with c-arm a gold standard with a minimal exposure to radiation.

Keywords: Fractures; Interlocking intramedullary nailing; Fluoroscopy; Africa

\section{Introduction}

Closed interlocked nail with c-arm guidance is the standard for the treatment of long bone fractures of the lower limbs [1] Therapeutic indications for surgical treatment of long bone fractures have evolved within the years, starting from the original works done by Kuntcsher to the static locking technic $[2,3]$ which was done using c-arm control. In low-income setting, it is still very difficult to carry out such procedures because of few or absent image intensifiers (c-arm) despite the necessity. Interlocking nailing without the use of image intensifier was studied by few authors. In 2007 firsts open reduction and static locked nailing was studied in Nigeria [4,5], then in 2011 in Uganda [6], Haiti [7] and in 2016 in Cameroon [8]. In 2021 closed interlocking nailing of the tibia without fluoroscopy was study in Cameroon [9]. Four essential aspects have been reported to be important in the achievement of a successful nailing without c- arm: the nail entry point, the progress of the guide wire through the distal segment, fracture reduction, and locking screws insertion [8,9]. The outcomes of these studies offer perspectives for management of diaphyseal fractures both in low income setting and high-income middle.

\section{Discussion}

Interlocking nailing without the use of image intensifier need a good pre-operative planning, and good technical surgery [10]. In all studies pre-operative planning was systematically using their X-rays [4-9]. These helped to evaluate the size of the nail and length of screws to be used. Specific ancillary devices were used to carry out this this technique: Surgical Implant Generation Network (SIGN) [4-7,10], Jiangsu Jinlu group Medical DEVICE CO [8] and Sharma orthopedic group [9]. To evaluate the surgical technique, outcomes proposed [9] are the quality of the nailing (position of the nail and the placement of the locking screws) which was assessed using 3 criteria [8]; the entry point; the insertion of the nail; the insertion of locking screws; bone consolidation; functional outcome, which was classified as excellent, good, fair, or poor according to criteria of Kalstrom and Olerud [11].

Quality of the nailing was characterized by the entry point which was globally good for all studies [4-10]. The insertion of the nail was done by open reduction for femur diaphyseal fractures $[4-8,10]$. It was done by minimal opening [8] or Closed reduction with external maneuvers [9] for tibia. There is not enough 
information on the percentage of missed distal interlocking in all studies. Nevertheless, for femur diaphyseal fractures, guifo et al noted $25 \%(5 / 20)[8]$. In tibia diaphyseal fractures a rate of $21,5 \%$ (3/14) [8] and 22,7\% (5/22) [9]. Functional and radiological outcomes were good and excellent in all studies. In low income setting findings suggested overall good outcomes of patients after interlocking nailing without c-arm. It can be proposed as an alternative to the gold-standard in sub-Saharan Africa in resources constraints settings. Its indications deserve to be specified and its practice taught or popularized without overshadowing the standard procedure with $\mathrm{C}$-arm guidance.

In high income middle some steps of this technique can be developed to reduce the use of fluoroscopy. Some steps like good pre-operative planning, anatomical location of entry point, reduction by external maneuvers (for tibia) or use of Specific ancillary devices for distal interlocking can limit the use of fluoroscopy only to the control of the key moment of surgery and no longer to imaging guide of nailing. This will decrease exposure to radiation in the operating room.

\section{Conclusion}

The practice of Interlocking nailing without the use of image intensifier had shown good results in studies conducted in subSaharan Africa. There is a need to improve equipment in subSaharan African hospitals to make trauma surgery with c-arm a gold standard with a minimal exposure to radiation.

\section{Source of Funding}

None.

\section{Declaration of Competing Interest}

None.

\section{References}

1. Bong MR, Kummer FJ, Koval KJ, Egol KA (2007) Intramedullary nailing of the lowerextremity: biomechanics and biology. J Am Acad Orthop Surg 15(2): 97-106.

2. Kuntcher BG (1958) The küntcher method of intramedullary fixation. J Bone Joint SurgAm 40: 17-26.

3. Kempf I, Grosse A, Lafforgue D (1978) L'apport du verrouillage dans l'enclouage cen-tromedullaire des os longs. Rev Chir Orthop 64: 631651.

4. Ikem IC, Ogunlusi JD, Ine HR (2007) Achieving interlocking nails without using animage intensifier. Int Orthop 31(4): 487-490.

5. Ikepeme I, Ngim N, Udosen A, Obiora O, Okokon E, et al. (2011) External Jig-aidedintramedullary interlocking nailing of diaphyseal fractures: experience from atropical developing centre. Int Orthop 35(1): 107-111.

6. Sekimpi P, Okike K, Zirkle L, Jawa A (2011) Femoral fracture fixation in developping countries: an evaluation of the Surgical Implant Generation Network (SIGN)Intramedullary nail. J Bone Joint Surg Am 93(19): 1811-1818.

7. White NJ, Sorkin AT, Konopka G, McKinley TO (2011) Surgical techique : static intramedullary nailing of the femur and tibia without intraoperative fluoroscopy. Clinical Orthopaedics and Related Research 469(12): 3469-3476.

8. Guifo ML, Muluem OK, Farikou I, Ngongang FO, Tekpa B, et al. (2016) Enclouage centromedullaire verrouille sans amplificateur de brillance au CHU de Yaounde: a propos de 34 cas. Revue de chirurgie orthopedique et traumatologique 102(1): 101-106.

9. Bombah FM, Mohamadou GE, Nana T, Ekani BY, Danwang C, et al. (2020) Outcomes of closed interlocking intramedullary nailing of the tibia without fluoroscopy in resource-limited settings: experience from two hospitals in Cameroon. The Pan African Medical Journal 38(87).

10. Zirkle LG, Shahab F, Shahabuddin (2016) interlocking intramedullary nail without fluoroscopy. Orthopedic Clinics 47(1): 57-66.

11. Kalstrom G, Olerud S (1977) Ipsilateral fracture of the femur and tibia. J Bone Joint Surg Am 59(2): 240-243.

\section{Your next submission with Juniper Publishers} will reach you the below assets

- Quality Editorial service

- Swift Peer Review

- Reprints availability

- E-prints Service

- Manuscript Podcast for convenient understanding

- Global attainment for your research

- Manuscript accessibility in different formats

( Pdf, E-pub, Full Text, Audio)

- Unceasing customer service

Track the below URL for one-step submission https://juniperpublishers.com/online-submission.php 